\title{
GENDER REPRESENTATION IN TEXTBOOK BAHASA INGGRIS GRADE X
}

\author{
Cynantia Rachmijati ${ }^{1}$, Sri Supiah Cahyati ${ }^{2}$ \\ cynan_tia@yahoo.com,srisupiahcahyati02@gmail.com \\ IKIP SILIWANGI
}

\begin{abstract}
According to ACDP Indonesia, many gender bias contents found in textbooks Bahasa Inggris in Indonesia settings. This study aims at examining the representation of gender on "Bahasa Inggris kelas $X$ " by Kemendiknas. The criteria of a good textbook should show the relationship of women and men in society based on their role, status, environment, culture and community structures which are displayed in the form of illustrations and descriptions of the sentence. Findings from the book regarding Text: 4,11\% visual characters, 28,77\% characters mentioned, 57,54\% social activities, and 9,58\% domestic activity. While findings regarding Visual: 88,89\% social activities and $11,11 \%$ regarding domestic. Furthermore, the Frequency of occurrence: for male $51,89 \%$. and female $48,11 \%$. Not too many domestic roles and settings found in the book probably because the book is created to in line with Curriculum 2013 where the main purpose of Curriculum 2013 is to develop social skills. It can be concluded that gender representation in this book is dominated by male.
\end{abstract}

Keywords: English textbook; gender representation.

\section{A. INTRODUCTION}

As a part of educational systems, textbooks and teaching materials are of paramount significance. Much attention was given in the early 1900s to assessing various manifestation of sexism and gender bias in foreign language textbooks, mainly English Language Teaching (ELT) textbooks. Since then, studies on language and gender have been carried out extensively. Numerous content and linguistic analyses of ELT textbooks as regard their representation of gender uncovered different aspect of sexism, in text and visuals.

Turner-Bowker (1996) suggests that textbooks teach children what behavior is appropriate or inappropriate and that they serve as a source that children acquire gender stereotype from. Gender identity is a social construct that is formed as individuals go through socialization process in their society and culture. Schooling naturally plays a pivotal role in this process and textbooks are part of schooling. Educational system in any country is shaped and affected by the prejudices, values and traditions held by the society; which are reflected in course books. In particular, it is important to focus on the awareness of equal rights and opportunities for men and women in the classroom. It is also important to relate English texts to the students' surroundings and social life. 
Furthermore we must examine whether textbooks represent different ways of living, social matters and traditions to expand the students' knowledge and understanding of a foreign language. Textbooks should therefore be written to suit both genders to be able to capture their interest and challenge gender stereotypes.

\section{B. LITERATURE REVIEW}

According to Analytical and Capacity Development Partnership (ACDP) Indonesia, there were many gender bias contents found in textbooks in Indonesia. They found in many kindergarten books, the illustration used were mostly males. Dewiki (2012) found that in textbooks of Bahasa Indonesia and mathematic textbooks in elementary, junior, and even high school there were 95\% of illustrations used were males. Furthermore, UNICEF (2007) also mentioned that in most textbooks boys were mentioned as smarter as and more creative than girls. Dads were mostly working at the office while moms working at home, such as cleaning, cooking, etc.

The criteria of a good textbook should show the relationship of women and men in society based on their role, status, environment, culture, and community structures which are displayed in the form of illustrations and descriptions of the sentence. This study aims at examining the representation of gender on English Language Textbook and finding the depiction of both male and female in social and domestic settings.

Gender is the socially constructed difference between men and women. According to Oxford Dictionary, gender is the condition of being male or female. Meanwhile Connel (1987) argues that there are different ideals for women and men. Thus gender differences are established through oppositions. As Connel states that "Women are supposed to be nurturing, suggestible, talkative, emotional, intuitive", while men, on the other hand, are supposed to be "aggressive, tough minded, taciturn, rational, analytic, and promiscuous".

Moreover, researcher like Barrie Thorne (1993) has observed children in school. She has particularly studies the ways children "pick up how to gender". Even newborn babies are treated differently because of their gender, they are named either female or male names and dressed in either blue or pink baby clothes. From the time a baby born, they tend to associates with many objects. Boys are associated with color blue, wild games and bruises. While girls are associated with color pink, clean, dolls, and quiet games. Girls learn to be polite, kind and take care of their appearance, while boys learn to be rough, demanding, and vigorous.

The role of gender in schools and how it has affected the student's goal fulfillment has been very much discussed in numerous texts and theories. Studies show that an early experience of gender equality is of importance for children's future. One study by the National Agency for Education in 2004 stated that Agency's annual compilation of final grades in compulsory school reveals that there are clear difference in results between boys and girls. Girls attain better results in subject tests and they are also more involved in discussing question dealing with human rights, environment, the future, and ethical opinions - compare to boys result. 
In Indonesia, especially in UUD 1945 article 31, it was stated that all citizens have the rights to get education. Therefore Indonesia is actively and progressively following world treaty regarding "education for all". It has been expected that all kids, no matter what gender, earned their education for 9 years: 6 years in elementary school and 3 years in junior high school. In order for them to be good citizens, literate (have reading-writing ability), and no gender discrepancy involving all education stakeholders.

Since the 1970s scholars and researchers have been concerned with the depiction of gender roles in English textbooks. Since then, numerous studies have examined the presentation of gender roles in textbooks, shedding light on both visual (e.g. drawings and photographs) and textual (e.g. conversation and written texts) presentation of female and male characters, such as Porreca (1984), Shteiwi (2003), Lee and Collins (2008), Hamdan and Jalabneh (2009), and Hall (2014).

Porreca (1984) studied sexism in fifteen of ELT textbooks. In six sorts of occurrences, either visual or textual, there are: (1) omission ratio of females compared to males, (2) occupational roles, (3) frequency of male to female nouns, (4)firstness, (5)masculine generic constructions, and (6) types and frequency of adjectives associated to either sex. The result found that there was evidence that sexism continued to flourish in ELS materials although females depicted only half as males in both text and illustrations. Shteiwi (2003) conducted a study on the representation of gender roles and he found that the majority of public roles were male dominated. Lee and Collins (2008) investigated whether recent improvements in the status of women in the country were mirrored in the gender representation and still authors maintained the old image. Hamdan and Jalabneh (2009) found that in many English language books men depicted as dominant and effective worker compared to female. Hall (2014) studied show that there was imbalance in gender representation due to the fact of culture and religious ideologies.

\section{RESEARCH METHODOLOGY}

The textbook analyzed in this study entitled "BAHASA INGGRIS KELAS X" written by Widiati, ZuliatiRohmah, and Furaidah published in the year of 2017. The book published by DepartemenPendidikanNasional in 2008 was also a BSE (BukuSekolahElektronik) which can be downloaded freely. The textbook has been especially written to meet the students' age group and interests. The book has 15 chapters and 233 pages. The textbook is selected for its content and visual analysis.

In analyzing the textbook, the researchers went through the following steps in order. First, the textbook was selected. Then the textbook was examined and studied in depth. Content analysis yielded to some categories proposed by Gharbavi (2012), they are:Text and Visual. Texts are categorized by visual characters, characters mentioned, social activities, and domestic activities. While Visual categorized by the number of men and women and whether it's social or domestic role.Pictures and illustrations inside the books were designed to enhance students' understanding of the context, lesson contents, and learning interest by making the book colorful and illustrative. The focus of the visual investigation was on the number of women and men in texts and pictures, and also the kind of social and domestic roles undertaken by women and men.A systematic recording and tabulation are made based on the characters and mentions of men and women in 
written text that include dialogues, stories, articles, literature, etc. Eventually, the researchers categorize the Frequency of appearance of male and female to get the representation of gender in the textbook.

\section{FINDINGS AND DISCUSSION}

The cover depicts the landmarks of the world, such as: Monas, Pisa, Pyramid, etc. This book has 233 pages and 15 chapters with various themes which going to be discussed by chapters.

Table. 1

\begin{tabular}{|c|c|c|}
\hline \multicolumn{3}{|c|}{ Analysis of unit 1: "Talking about self" } \\
\hline \multirow[t]{5}{*}{ Visual } & A female student & Social \\
\hline & 4 females chatting & Social \\
\hline & A female student reading at the & Social \\
\hline & library & \\
\hline & 2 males speaking & Social \\
\hline \multirow[t]{5}{*}{ Text } & Greeting & Social \\
\hline & Email & $\begin{array}{c}\text { Social,characters mentioned, } \\
\text { domestic role }\end{array}$ \\
\hline & Letters & $\begin{array}{c}\text { Social,characters mentioned, } \\
\text { domestic role }\end{array}$ \\
\hline & Vocabularies & $\begin{array}{c}\text { Social,characters mentioned, } \\
\text { domestic role }\end{array}$ \\
\hline & Grammar & $\begin{array}{c}\text { Social,characters mentioned, } \\
\text { domestic role }\end{array}$ \\
\hline $\begin{array}{c}\text { Frequency of } \\
\text { appearance of } \\
\text { male and female }\end{array}$ & $\begin{array}{r}\mathrm{M} \\
\text { Fem }\end{array}$ & \\
\hline
\end{tabular}

Table. 2

Analysis of unit 2: "Congratulating and Complimenting Others"

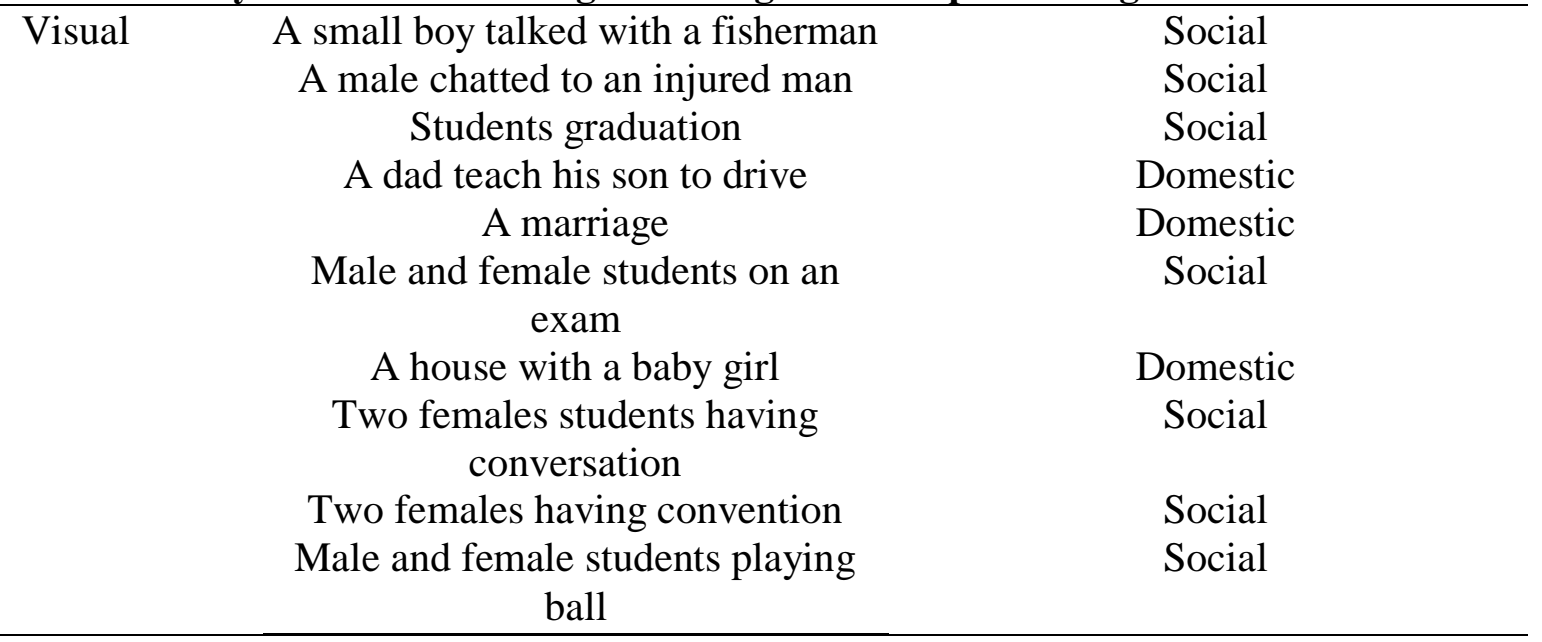




\begin{tabular}{c|cc}
\hline \multicolumn{1}{c|}{ Text } & $\begin{array}{c}\text { Quote by Mark Zuckenberg } \\
\text { Conversation on congratulation } \\
\text { Vocabularies }\end{array}$ & $\begin{array}{c}\text { Social } \\
\text { Social, characters mentioned, } \\
\text { domestic role }\end{array}$ \\
& Conversation on complimenting & $\begin{array}{c}\text { Social, characters mentioned } \\
\text { Social, characters mentioned }\end{array}$ \\
\hline $\begin{array}{c}\text { Frequency of } \\
\text { appearance of }\end{array}$ & Male $: 15$ \\
male and female & Female $: 15$ \\
\hline
\end{tabular}

Table.3

Analysis of unit 3: "What Are You Going To Do Today?"

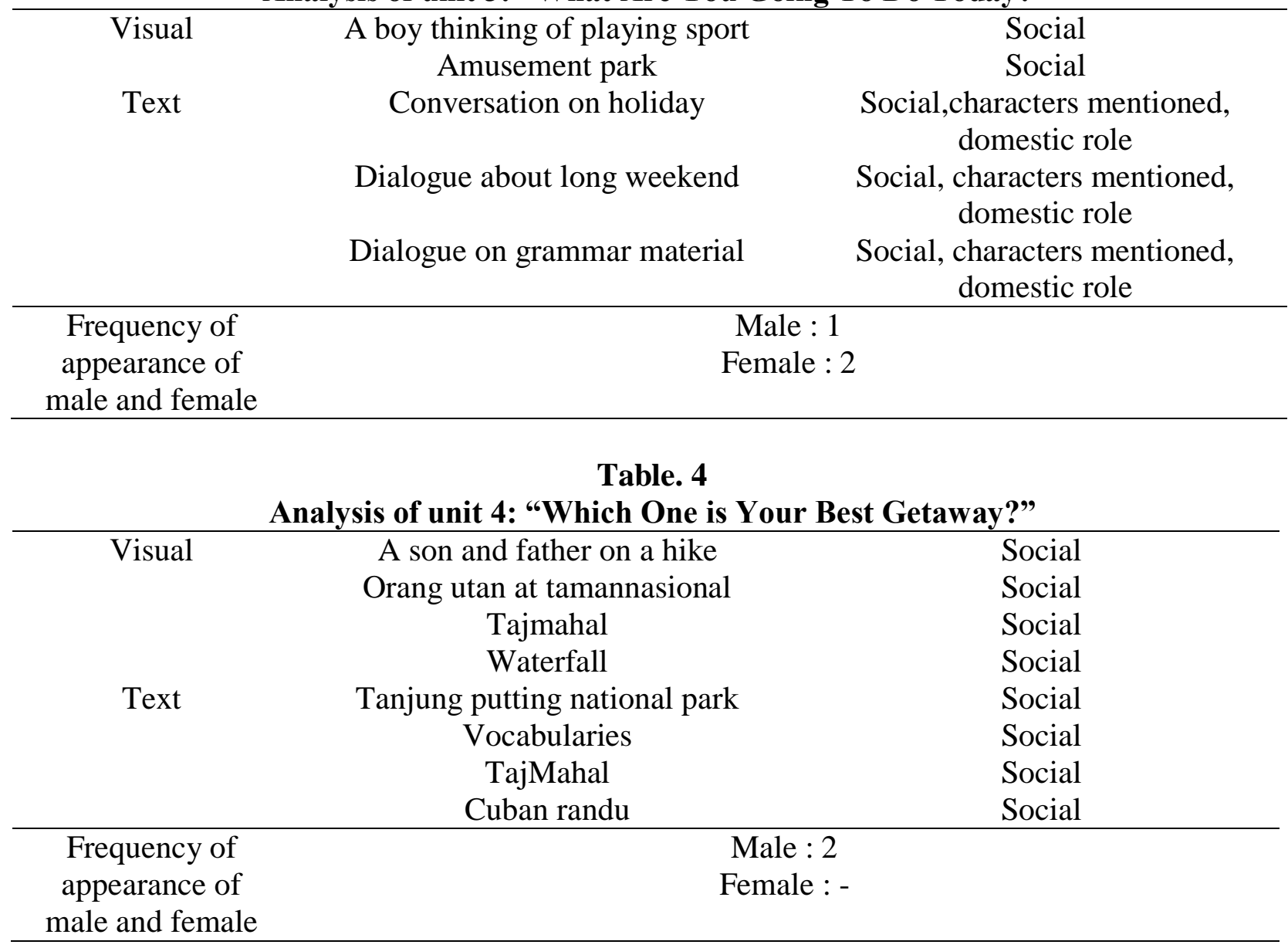


Table. 5

Analysis of unit 5: "Let's Visit Niagara Falls"

Visual

Text

\section{Niagara falls}

A male teacher talking to a female student

A male pilot

A female visiting Niagara falls

Two males talking about candi

Borobudur

Students in a middle of a discussion

A male student working on an

assignment

Niagara falls

\section{Social \\ Social}

Social

Social

Social

Social

Social

Social

\begin{tabular}{cc}
\hline Frequency of & Male $: 1$ \\
appearance of & Female $: 2$ \\
male and female & \\
\hline
\end{tabular}

Table. 6

Analysis of unit 6: "Giving Announcement"

\begin{tabular}{ccc}
\hline Visual & $\begin{array}{c}\text { A male giving announcement } \\
\text { A student on a listening test } \\
\text { Text }\end{array}$ & Cocial \\
& Cancelation on JYJ concert & Social \\
& Announcement regarding medical & Characters mentioned \\
& school & Social \\
& Announcement regarding conferences & Social \\
Frequency of & Club announcement & Social, characters mentioned \\
appearance of & & Male :5 \\
male and female & Female : 2 & \\
\hline
\end{tabular}

Table. 7

Analysis of unit 7: "The Wright Brothers"

\begin{tabular}{ccc}
\hline $\begin{array}{c}\text { Visual } \\
\text { Text }\end{array}$ & $\begin{array}{c}\text { The wright brothers with a plane } \\
\text { Interview with the wright brothers } \\
\text { Quote from Frank Sinatra }\end{array}$ & $\begin{array}{c}\text { Social } \\
\text { Characters mentioned } \\
\text { Social }\end{array}$ \\
\hline $\begin{array}{c}\text { Frequency of } \\
\text { appearance of } \\
\text { male and female }\end{array}$ & Male $: 3$ & \\
\hline
\end{tabular}


Table. 8

Analysis of unit 8: "My Idol"

Visual

An athlete give out signature

Social

AnggunC.Sasmi

Social

Lionel Messi

Social

Afghan

Social

A male student working on a laptop

Social

Text

Meeting my idol

Social, characters mentioned

Vocabularies about idol

\begin{tabular}{cc}
\hline Frequency of & Male $: 2$ \\
appearance of & Female $: 2$ \\
male and female & \\
\hline
\end{tabular}

Table. 9

Analysis of unit 9: "The Battle of Surabaya"

$\begin{array}{ccc}\text { Visual } & \text { Bung Tomo } & \text { Social } \\ \text { Text } & \text { Heroes day in Indonesia } & \text { Social, characters mentioned } \\ & \text { Dialogue on green campus } & \text { Social }\end{array}$

Frequency of

Male :4

appearance of male

Female : 2

and female

Table. 10

Analysis of unit 10: "BJ Hobbies"

\begin{tabular}{|c|c|c|}
\hline $\begin{array}{c}\text { Visual } \\
\text { Text }\end{array}$ & $\begin{array}{c}\text { BJ.habibie } \\
\text { Biography of BJ Habibie } \\
\text { Dialogue of BJ Habibie admirer }\end{array}$ & $\begin{array}{c}\text { Social } \\
\text { Social, characters mentioned } \\
\text { Social }\end{array}$ \\
\hline $\begin{array}{l}\text { Frequency of } \\
\text { appearance of male } \\
\text { and female }\end{array}$ & \multicolumn{2}{|c|}{$\begin{array}{c}\text { Male }: 4 \\
\text { Female }: 5\end{array}$} \\
\hline \multicolumn{3}{|c|}{$\begin{array}{l}\text { Table. } 11 \\
\text { Analysis of unit 11: “Cut NyakDhien" }\end{array}$} \\
\hline $\begin{array}{c}\text { Visual } \\
\text { Text }\end{array}$ & $\begin{array}{c}\text { Cut NyakDhien } \\
\text { Biography of Cut NyakDhien } \\
\text { Quote of Les Brown }\end{array}$ & $\begin{array}{c}\text { Social } \\
\text { Social, characters mentioned } \\
\text { Social }\end{array}$ \\
\hline $\begin{array}{l}\text { Frequency of } \\
\text { appearance of male } \\
\text { and female }\end{array}$ & $\begin{array}{c}\text { Male }: 7 \\
\text { Female }: 7\end{array}$ & \\
\hline
\end{tabular}


Table. 12

Analysis of unit 12: "Issumboshi (Japanese Fairy Tale)"

\begin{tabular}{|c|c|c|}
\hline $\begin{array}{l}\text { Visual } \\
\text { Text }\end{array}$ & $\begin{array}{c}\text { A grandma } \\
\text { A princess } \\
\text { Story of issumboshi } \\
\text { Vocabularies on bullying } \\
\text { Story of Kancil } \\
\text { Quote of Talmud }\end{array}$ & $\begin{array}{c}\text { Social } \\
\text { Social } \\
\text { Social, domestic } \\
\text { Social, domestic } \\
\text { Social } \\
\text { Social } \\
\end{array}$ \\
\hline $\begin{array}{c}\text { Frequency of } \\
\text { appearance of male } \\
\text { and female }\end{array}$ & \multicolumn{2}{|c|}{$\begin{array}{c}\text { Male }: 7 \\
\text { Female }: 6\end{array}$} \\
\hline \multicolumn{3}{|c|}{$\begin{array}{c}\text { Table. } 13 \\
\text { Analysis of unit 13: "MalinKundang" } \\
\end{array}$} \\
\hline Visual & $\begin{array}{c}\text { Rumahgadang } \\
\text { Malinkundang illustrated } \\
3 \text { male students and } 1 \text { female } \\
\text { students having a discussion }\end{array}$ & $\begin{array}{c}\text { Domestic } \\
\text { Social, domestic } \\
\text { Social }\end{array}$ \\
\hline Text & $\begin{array}{c}\text { The legend of malinkundang } \\
\text { Vocabularies on parenting } \\
\text { Quote of M.Ali }\end{array}$ & $\begin{array}{l}\text { Visual, characters } \\
\text { Social, domestic } \\
\text { Social }\end{array}$ \\
\hline $\begin{array}{l}\text { Frequency of } \\
\text { appearance of male } \\
\text { and female }\end{array}$ & \multicolumn{2}{|c|}{$\begin{array}{r}\text { Male : } 3 \\
\text { Female }: 4\end{array}$} \\
\hline
\end{tabular}

Table. 14

Analysis of unit 14: "Strong Wind"

\begin{tabular}{lll}
\hline Visual & Coconut trees blowing bythe wind & Social \\
& $\begin{array}{l}\text { A pantomime } \\
\text { A drama group performing } \\
\text { Two males and two females in an } \\
\text { office meeting }\end{array}$ & $\begin{array}{l}\text { Social } \\
\text { Social }\end{array}$ \\
& $\begin{array}{l}\text { Pantomime } \\
\text { Text }\end{array}$ & $\begin{array}{l}\text { Strong wind } \\
\text { Quote of Oprah Winfrey }\end{array}$ \\
& Social \\
& Social \\
\hline $\begin{array}{l}\text { Frequency } \\
\text { appearance of male } \\
\text { and female }\end{array}$ & Female : 7 & \\
\hline
\end{tabular}


Table. 15

Analysis of unit 15: "You've Got A Friend"

\begin{tabular}{ccc}
\hline Visual & $\begin{array}{c}\text { A female singing } \\
\text { A male student comforting a } \\
\text { friend }\end{array}$ & $\begin{array}{c}\text { Social } \\
\text { Social }\end{array}$ \\
& $\begin{array}{c}3 \text { female students taking selfies } \\
\text { A male talking with a friend on } \\
\text { lake }\end{array}$ & $\begin{array}{c}\text { Social } \\
\text { Social }\end{array}$ \\
Text & $\begin{array}{c}\text { Song lyric "you've got a friend" } \\
\text { Poem about friends } \\
\text { Quote of Les Brown }\end{array}$ & $\begin{array}{c}\text { Visual } \\
\text { Social } \\
\text { Frequency of }\end{array}$ \\
$\begin{array}{c}\text { appearance of male } \\
\text { and female }\end{array}$ & Social \\
\hline
\end{tabular}

The content analysis of the selected textbook includes Text and Visual analysis. The result reveals that the book "Bahasa Inggris kelas $X$ " has various topics which suitable for students' age group and interest. The book has practice and exercise for each language skills and many of the topics include social activities and regard some idols, such as: Afghan, JYJ, etc which is suitable for youngster.

Based on the tables above, it can be summarized that the total number of data regarding Text in the book is:

\begin{tabular}{lcc}
\hline Social activities & 42 & $57.54 \%$ \\
Domestic activity & 7 & $9.58 \%$ \\
Characters mentioned & 21 & $28.77 \%$ \\
Visual characters & 3 & $4.11 \%$ \\
\hline
\end{tabular}

It shows that the most amount of activity is social activity, and characters come second, whereas domestic and visual are the third and fourth.

Meanwhile, the total number of findings regarding Visualin the book is:

\begin{tabular}{lcc}
\hline Social activities & 48 & $88.89 \%$ \\
Domestic activities & 6 & $11.11 \%$ \\
\hline
\end{tabular}

In visual, social activities dominated rather than domestic activities. There are many visuals regarding going out, hanging out, and socializing with people. Therefore, the domestic activity is not as much as the social activities. 
Whereas the Frequency of occurrence of male and female in the book is:

\begin{tabular}{lll}
\hline Male & 55 & $51.89 \%$ \\
Female & 51 & $48.11 \%$ \\
\hline
\end{tabular}

The frequency of appearance of male and female can be seen from the table above. It showed that male appeared more than female in the book.These results agreed with Hamdan and Jalabneh (2009), who found that in many English language books men depicted as dominant and effective worker compared to female. In this book, male mentioned in many chapters and portrayed as father figure, worker, etc. whereas female only portrayed most as students or clerk. Hall (2014) in his study showed that there was imbalance in gender representation due to the fact of culture and religious ideologies. In Indonesia, even though gender equity is already improving, society still regard male as more dominated figure than female because of religion and culture.

\section{E. CONCLUSIONS AND SUGGESTIONS}

In conclusion, the findings of this research can be stated as follow:

1. Male showed and mentioned in this book is better than female, even though female also showed and mentioned not too far behind.

2. Male depicted in varieties of social settings from school, office, nature, houses, parties, graduation ceremony, etc. Whereas female depicted in social settings, such as school or office.

3. Not too many domestic roles and settings found in the book probably because the book is written to inline with Curriculum 2013, where the main purpose of Curriculum 2013 is to develop social skills.

4. Findings regarding Textshowed: $4,11 \%$ visual characters, $28,77 \%$ characters mentioned, $57,54 \%$ social activities, and 9,58\% domestic activity; meanwhile findings regarding Visual:88,89\% social activities, and 11,11\% regarding domestic; whereas the Frequency of occurrence for male $51,89 \%$ and female $48,11 \%$.It can be concluded that gender representation in this book is dominated by male.

There are many factors which caused gender discrepancies, such as: culture, tradition, religion, country's policy, etc. Therefore education, whether formal or informal, is the best platform to face any gap between male and female as roles in society. Through this research, the researchers would like to propose some suggestions as follow:

1. The reference materials in the English textbooks needs to be revised and revisited to portrayed ideally for both genders.

2. Gender equality and gender discrepancies needs to be socialized to the teachers to make them familiar with this issues. Teachers should have good perspectives regarding gender bias and inequality in teaching materials as well, therefore they can be a role model, provide examples, and guide students to have positive self image.

3. Materials developers, textbooks writers, and the Education Department should examine every aspect of textbooks, in text and visuals, to assure a fair representation of both males and females. 


\section{F. REFERENCES}

ACDP Indonesia. (2013).Kesetaraan Gender dalam Pendidikan Di Indonesia. $\quad$ Retrieved from: http://www.batukarinfo.com

Connel,RW.. (1987).Gender And Power: Society, The Person, And Social Politic. Stanford: Stanford University Press

Dewiki, Santi. (2012).Perspektif Gender dalam Bahan Ajar Cetak Pendidikan Jarak Jauh: Studi Kasus pada Bahan Ajar Cetak Program Studi. D2 Pendidikan olah raga FKIPU”.Retrievedfrom :http://www.berperspektifgemder.santi.ut.acid.pdf

Gharbavi \& Mousavi. (2012).A Content Analysis Of Textbooks: Investigating Gender Bias As Social Prominence In Iranian High School English Textbooks. English linguistic Research retrieved from: http://www.sciecu.edu.ca/elr

Hall,Mahnaz. (2014).Gender Representation in Current EFL Textbooks In Iranian Secondary Schools. Journal of Language Teaching and Research .Vol. 5 Issue 2 Year 2014

Hamdan \& Jalabneh. (2009).Topics in EFL Textbooks and The Question of Gender Dominance. The International Journal of Language Society and Culture.

Hornby, A.S. (1995).Oxford's Learners' Dictionary of Current English. New York: $\quad$ Oxford University.

Lee \& Collins. (2008). Gender voices in Hong Kong English textbooks - some past and current practices.

National Agency for Education. (2004).Analytical Report on Educational National Focal Point. Retrieved from: https://fra.europa.eu/sites/default/files/.../294-R4-EDU SE.pdf

Porecca, Karen.(1984).Sexism in current ESL textbooks. TESOL Quarterly Vol. 18 No 4 Year 1984

Shteiwi, Musa.(2003).Gender Role Stereotypes in Primary School Textbooks in Jordan, DIRASAT, Social and Human Sciences

Turner, Bowker. (1996).Gender Stereotypes Descriptors in Children's Picture Books. Long Beach: University of California

Thorne, Barrie. (1993).Boys and Girls in School. New Brunswick: Rutgers University Press

UNESCO. (2007).EFA Global Monitoring Report: Gender and Education For All. retrieved from: http://www.unesco.org/education/GMR/2007/Full_report.pdf 